\title{
Edukasi Kesehatan Masyarakat Melalui Disinfaksi dan Penggunaan Masker Sebagai Upaya Pencegahan Penyebaran Virus Covid-19 di Panti Asuhan Al-Isti'anah Kediri Kabupaten Lombok Barat
}

\author{
Dwi Kartika Risfianty ${ }^{1 *}$, Indrawati ${ }^{2}$, Farah Heniati Santosa ${ }^{3}$, \\ Samsul Bahri ${ }^{4}$, Samsuriadi $^{5}$ \\ ${ }^{1 *}$ Biologi, FMIPA, ${ }^{2,3,4,5}$ Pendidikan Matematika, FKIP \\ Universitas Nahdlatul Wathan Mataram \\ *Corresponding Author Email: flowmath@gmail.com
}

\begin{abstract}
The purpose of implementing this service activity is to make efforts to break the Covid-19 chain by distributing disinfectants, disinfectants and masks for administrators and foster children of the Al-Isti'anah Orphanage Kediri, West Lombok. The method of implementing this service is by providing disinfection tools, disinfectant fluids, and masks to the administrators of the AlIsti'anah Orphanage Kediri, West Lombok. The results of this service activity were providing disinfection kits, disinfectant fluids and masks to the AlIsti'anah Orphanage, Kediri, West Lombok. In addition, the community service team provided education about the importance of disinfection in the orphanage area to reduce the possible risk of spreading and spreading the covid-19 virus to the caretakers and children of the residents of the Al-Isti'anah orphanage, Kediri, West Lombok. By carrying out health education through disinfection and the use of masks, the administrators of the Al-Isti'anah Orphanage better understand the importance of disinfection in the orphanage area and the obedience of caregivers and children in using masks when interacting in the orphanage environment.
\end{abstract}

\begin{abstract}
Abstrak: Tujuan pelaksanaan kegiatan pengabdian ini adalah untuk melakukan upaya pemutusan mata rantai Covid-19 melalui pembagian alat disinfaksi, desinfektan dan masker bagi para pengurus dan anak asuh Panti Asuhan AlIsti'anah Kediri Kabupaten Lombok Barat. Metode pelaksanaan kegiantan pengabdian ini yakni dengan memberikan alat disinfaksi, cairan disenfektan, dan masker kepada para pengurus Panti Asuhan Al-Isti'anah Kediri Kabupaten Lombok Barat. Hasil kegiatan pengabdian ini yakni memberikan alat disinfaksi, cairan desinfektan dan masker kepada Panti Asuhan Al-Isti'anah Kediri Kabupaten Lombok Barat. Selain itu tim pengabdian memberikan edukasi tentang pentingnya melakukan disinfaksi pada area panti asuhan untuk mengurangi kemungkinan resiko penyebaran dan penularan virus covid-19 pada pengurus dan anak-anak penghuni panti asuhan Al-Isti'anah Kediri Kabupaten Lombok Barat. Dengan melakukan edukasi kesehatan melalui disinfaksi dan penggunaan masker, para pengurus Panti Asuhan Al-Isti'anah lebih memahami pentingnya melakukan disinfaksi pada area panti asuhan dan ketaatan para pengasuh dan anak-anak asuh dalam menggunakan masker ketika berinteraksi di lingkungan Panti Asuhan.
\end{abstract}

Article History:

Received: 07-03-2021

Reviewed: 09-04-2021

Accepted: 14-04-2021

Published: 05-05-2021

Key Words:

Health Education,

Disinfectants,

Masks.

Sejarah Artikel:

Diterima: 07-03-2021

Direview: 09-04-2021

Disetujui: 14-04-2021

Diterbitkan: 05-05-2021

\section{Kata Kunci:}

Edukasi Kesehatan, Desinfektan, Masker.

How to Cite: Indrawati, I., Santosa, F., Bahri, S., \& Samsuriadi, S. (2021). Edukasi Kesehatan Masyarakat Melalui Disinfaksi dan Penggunaan Masker Sebagai Upaya Pencegahan Penyebaran Virus Covid-19 di Panti Asuhan Al-Isti'anah Kediri Kabupaten Lombok Barat. Jurnal Pengabdian UNDIKMA, 2(1), 104-109. doi:https://doi.org/10.33394/jpu.v2i1.3713 


\section{Pendahuluan}

Kasus Covid-19 di Indonesia merupakan bagian dari pandemi penyakit koronavirus 2019 (Covid-19) yang sedang berlangsung di seluruh dunia. Penyakit ini disebabkan oleh koronavirus sindrom pernapasan akut berat 2 (SARS-CoV-2). Corona virus atau Covid-19 menupakan virus yang pertama kali muncul di Wuhan Cina pada awal tahun 2020. World Health Organisation mencatat bahwa setidaknya 199 negara (WHO, 2020) telah terpapar oleh corona virus dan sejak bulan Maret 2020 penyebaran corona virus di Indonesia semakin meningkat. Tingkat kematian yang diakibatkan oleh corona virus di Indonesia tercatat dua kali lipat lebih banyak dibandingkan dengan angka kematian akibat corona virus didunia yaitu mencapai 8,67\% sejak bulan Maret hingga Mei 2020 (Gugus Tugas Percepatan Penanganan Covid-19, 2020).

Kasus positif Covid-19 di Indonesia pertama kali dideteksi pada Maret 2020, pada saat dua orang terkonfirmasi tertular dari seorang warga negara Jepang. Dalam waktu yang sangat cepat kasus positif Covid-19 menyebar ke berbagai provinsi di Indonesia, termasuk Nusa Tenggara Barat. Berdarkan Dinas Kesehatan NTB (2021) Data Covid-19 Nusa Tenggara Barat update 31 Maret 2021 mencatat pasien covid-19 sebanyak 10.946 dengan rincian rawat sebanyak $985(9,00 \%)$, sembuh sebanyak 9489 (86,89\%), dan meninggal sebanyak $472(4,31 \%)$.

Penularan corona virus dapat terjadi memalui droplet yang dikeluarkan dari hidung atau mulut penderita positif Covid-19 ketika mengalami bersin atau batuk. Penularan bisa terjadi secara tidak langsung akibat menempelnya droplet penderita positif Covid-19 yang menempel pada benda yang tidak sengaja tersentuh dan masuk ke dalam tubuh dengan menyentuh hidung, mata atau mulut. Oleh karena itu, untuk dapat mencegah terjadinya penularan Covid-19, masyarkat dihimbau untuk menerapkan Perilaku Hidup Bersih dan Sehat (PHBS) (Rusdi et al, 2021), melakukan social distancing atau menghidari kerumunan, mencuci tangan dengan sabun dan air mengalir, menggunakan masker, menggunakan handsanitizer (Meri et al, 2020), dan melakukan disinfaksi (Athena et al, 2020).

Disinfeksi merupakan proses pengurangan mikroorganisme berbahaya dengan menggunaan bahan aktif atau desinfektan yang mampu membunuh mikroorganisme berbahaya. Desinfektan merupakan senyawa aktif yang dapat digunakan untuk mengandalikan, mencegah hingga menghancurkan mikroorganisme berbahaya. Selain melakukan disinfaksi rutin, pencegahan penularan Covid-19 yaitu dengan menggunakan masker dan menerapkan social distancing ketika melakukan kegiatan diluar rumah dan ketika berada dikerumunan (Indrawati et al, 2020).

Disinfaksi dan penggunaan masker sebagai upaya pencegahan penyebaran virus Covid-19 di Panti Asuhan Al-Isti' anah Kediri Kabupaten Lombok Barat merupakan bentuk kepedulian FMIPA dan FKIP Universitas Nahdlatul Wathan Mataram untuk ambil bagian dalam upaya pemutusan mata rantai penularan Covid-19 di tengah-tengah masyarakat. Pemilihan lokasi Panti Asuhan Al-Istihanah Kediri Kabupaten Lombok Barat didasarkan pada kondisi panti asuhan sebagai klaster dengan kasus terkonfirmasi positif terbesar di Kabupaten Lombok Barat sehingga perlu mendapat perhatian serius dari berbagai pihak. Selain itu panti asuhan merupakan tempat berkumpul anak-anak kurang mampu yang mencari perlindunagn dan pendidikan.

Pengabdian Masyarakat ini dilaksanakan di Panti Asuhan Al-Istihanah Kediri Kabupaten Lombok Barat yang memiliki anak asuh sebanyak 30 orang dan jumlah pengasuh sebanyak 6 orang. Panti Asuhan merupakan tempat yang rentan dalam penularan Covid-19 dikarenakan Panti Asuhan merupakan tempat yang memiliki penghuni dalam jumlah besar. 
Maka dari itu, Fakultas Matematika dan Ilmu Pengetahuan Alam bersama dengan Fakultas Keguruan dan Ilmu Pendidikan Universitas Mataram tertarik untuk mengadakan pengabdian kepada masyarakat dengan membagikan masker dan pemberian seperangkat alat dan bahan untuk desinfektan sebagai upaya untuk melakukan pencegahan dan pemutusan mata rantai penularan Covid-19.

\section{Metode Pengabdian}

Metode pelaksanaan kegiatan Pengabdian kepada Masyarakat (PKM) ini yaitu dengan melakukan edukasi kesehatan kepada para pengasuh Panti Asuhan Al-Istihanah Kediri tentang pentingnya melakukan disinfaksi pada area Pondok Pesantren dan ketaatan para pengasuh dan anak-anak asuh dalam menggunakan masker ketika berinteraksi di lingkungan Panti Asuhan. Dari perencanaan kegiatan, pengumpulan donasi hingga pelaksaan kegiatan diperlukan waktu selama 2,5 bulan atau 76 hari. Selama pelaksanaan kegiatan pengabdian Ketua PKM, Anggota PKM hingga para pengasuh Panti Asuhan Al-Istihanah menerapkan protokol kesehatan yaitu menggunakan masker dan melakukan social distancing selama melakukan pengarahan hingga penyerahan alat disinfaksi, cairan desinfektan dan masker.

\section{Hasil Pengabdian dan Pembahasan}

Corona virus atau Covid-19 memiliki gejala ringan seperti batuk dan demam hingga gejala berat seperti sesak nafas dan penurunan kadar oksigen dalam tubuh. Penyebaran covid19 bisa terjadi melalui droplet yang menempel pada benda mati hingga melalui kontak fisik dengan penderita positif covid-19. Selain melakukan social distancing, cuci tangan dengan sabun dan air mengalir selama 20 detik, menggunaan hand sanitizer, menyemprotkan desinfektan hingga penggunaan masker, upaya lain yang dapat dilaukan untuk mengurangi kemungkinan tertular covid-19 yaitu dengan mengurangi intesitas menyentuh wajah setelah bepergian dan menyentuh benda ditempat umum (Larasati \& Hariwibowo, 2020). Kebiasaan menggunakan masker di tempat umum, sering mencuci tangan dan jaga jarak (social distancing) merupakan protokol Covid-19 yang sering disosialisasikan kepada masyarakat. Kegiatan ini telah didukung oleh berbagai pihak baik secara perorangan, kelompok sosial ataupun secara kelembagaan. Hal ini menunjukkan adanya kepedulian yang besar untuk bersama-sama memutus mata rantai penularan Covid-19.

Masker merupakan Alat Pelindung Diri atau APD yang saat ini wajib digunakan oleh masyarakat jika melakukan kegiatan diluar rumah. Penggunaan masker merupakan salah satu metode yang efektif untuk mengurangi kemungkinan terjadinya penularan covid-19 akibat terpapar droplet ketika berkomunikasi dengan orang lain. Masker tidak hanya digunakan oleh penderita covid-19 tetapi juga digunakan oleh individu sehat. Penggunaan masker merupakan cara pencegahan yang paling mudah dan murah namun sangat efektif untuk mengurasi resiko penularan covid-19 (Fitriasari, 2020).

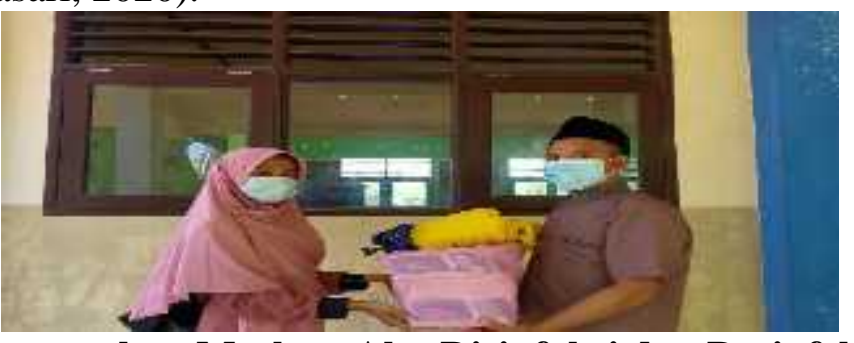

Gambar 1. Penyerahan Masker, Alat Disinfaksi dan Desinfektan Kepada Pimpinan Panti Asuhan Al-Isti'anah Kediri Kabupaten Lombok Barat. 
Masker yang beredar dimasyarakat saat ini begitu beragam, mulai dari masker berbahan scuba, masker kain, masker medis hingga masker N95. Masker medis dan masker N95 memiliki efektifitas tertinggi yaitu sekitar 80-90\%, masker kain 3 lapis memiliki efektifitas sekitar 50-70\% dan masker berbahan scuba memiliki efektifitas paling rendah yaitu $0-5 \%$ (Fitriasari, 2020), sehingga penggunaan masker scuba tidak disarankan untuk digunakan sebagai salah satu alat pencegahan penularan covid-19. Hal ini merupakan upaya yang bisa dilakukan setiap individu untuk mencegah penularan covid 19. Kegiatan pembagian masker, alat disinfaksi dan cairan desinfektan ini mendapat antusias dari para penghuni panti asuhan. Dokumentasi kegiatan dapat dilihat pada Gambar 1.
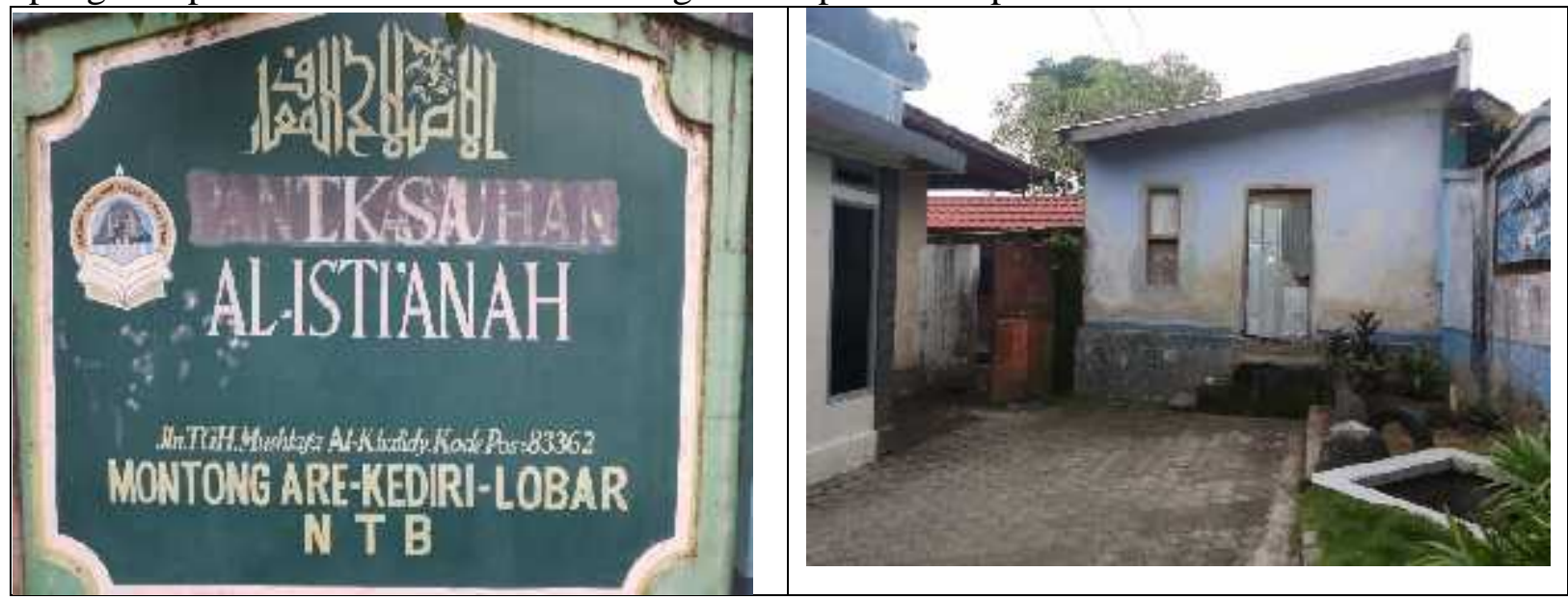

Gambar 2. Kondisi Panti Asuhan Al-Isti’anah Kediri Kabupaten Lombok Barat

Corona virus diketahui memiliki kemampuan bertahan pada permukaan plastik dan stainless steel selama 72 jam, pada permukaan karton selama 24 jam dan pada permukaan tembaga selama kurang dari 4 jam (Mahendra et al, 2020). Disinfaksi dilakukan dengan tujuan untuk mendekontaminasi mikroorganisme berbahaya yang mengkontaminasi permukaan benda. Desinfektan merupakan bahan kimia yang bersifat toksik sehingga penggunaan desinfektan harus dengan takaran dan protokol disinfaksi yang tepat. Disinfaksi biasanya dilakukan dimana biasanya terdapat kerumunan. Beberapa jenis desinfektan memilliki kemampuan yang cukup baik untuk membunuh mikroorganisme pada permukaan kayu, lantai, dinding, besi, kaca dan berbagai benda mati. Selain itu, desinfektan memiliki harga dan jenis yang murah serta mudah didapatkan dipasaran. Sehingga penggunaan desinfektan lebih banyak menjadi pilihan masyarakat untuk mengurangi resiko penularan covid-19 dimasyarakat.

Sebelum dilakukan menyerahan alat disinfaksi dan desinfaktan, Anggota PKM memberikan pemahaman kepada para pengurus Panti Asuhan Al-Isti' anah tentang tata cara penyemprotan serta takaran desinfektan yang tepat. Desinfektan yang diberikan yaitu Hidrogen Peroksida 3\% $\left(\mathrm{H}_{2} \mathrm{O}_{2} 3 \%\right)$ yang memiliki sifat sebagai antiseptik dan desinfektan (Ihsan et al, 2020). Pelaksanaan desinfaksi di lingkungan Panti Asuhan Al-Isti'anah dilakukan dengan menyemprotkan cairan desinfektan pada permukaan benda yang berada diseluruh ruangan panti asuhan. Proses disinfaksi dilakukan dengan tetap menerapkan protokol kesehatan yaitu menggunakan masker dan mengosongkan ruangan terlebih dahulu untuk menghidari terjadinya paparan atau terhirupnya desinfektan oleh para penghuni panti asuhan yang merupakan anak-anak. Lingkungan yang sehat akan membantu masyarakat yang tinggal dalam lingkungan tersebuat merasa nyaman, tenang dan bahagia sehingga dapat menikmati hidup. Tubuh yang sehat dapat diperoleh dengan mengkonsumsi makanan yang 
bersih dan sehat serta lengkap akan gizi, selain itu dengan menerapkan pola hidup bersih akan menguatkan system imun tubuh. Tubuh yang sehat akan sangat sulit untuk diinfeksi oleh berbagai agen penyakit berbahaya seperti Covid-19 atau penyakit lainnya, karena tubuh yang sehat memiliki pertahanan (imunitas) yang kuat dan mudah melakukan penyebuhan sendiri (Risfianty \& Indrawati, 2020).

Panti Asuhan Al-Istihanah Kediri Kabupaten Lombok Barat yang memiliki anak asuh sebanyak 30 orang dan jumlah pengasuh sebanyak 6 orang. Dokumentasi lingkungan panti asuhan dapat dilihat pada gambar 2. Tiga hal penting yang ditanamkan kepada para pengurus Panti Asuhan Al-Isti'anah adalah bagaimana setiap orang berusaha untuk sering mencuci tangan, memakai masker dan menjaga jarak. Untuk itu kegiatan ini dilakukan dengan memberikan edukasi kesehatan melalui disinfaksi dan penggunaan masker. Dengan demikian para pengurus Panti Asuhan Al-Isti' anah lebih memahami pentingnya melakukan disinfaksi pada area panti asuhan. Selain itu para pengasuh dan anak-anak asuh Panti Asuhan AlIsti' anah lebih taat dalam menggunakan masker baik ketika berinteraksi di lingkungan Panti Asuhan maupun diluar lingkungan panti asuhan. Luaran yang diharapkan dari kegiatan pengabdian ini adalah meningkatnya kesadaran masyarakat khususnya para pengurus dan dan penghuni Panti Asuhan Al-Isti'anah untuk bersama-sama berupaya mencegah penularan covid 19. Program ini sangat efektif untuk dilaksanakan sebab masih banyak orang-orang diluar sana yang membutuhkan uluran tangan sebagai bentuk bantuan. Walaupun harganya tidak seberapa namun besar manfaatnya untuk mereka.

\section{Kesimpulan}

Kesimpulan dari kegiatan Pengabdian Kepada Masyarakat adalah selain memberikan alat disinfaksi, cairan desinfektan dan masker kepada Panti Asuhan Al-Isti'anah Kediri Kabupaten Lombok Barat, tetapi juga memberikan edukasi tentang pentingnya melakukan disinfaksi pada area panti asuhan untuk mengurangi kemungkinan resiko penyebaran dan penularan virus covid-19 pada pengurus dan anak-anak penghuni panti asuhan Al-Isti'anah Kediri Kabupaten Lombok Barat. Dengan melakukan edukasi kesehatan melalui disinfaksi dan penggunaan masker, para pengurus Panti Asuhan Al-Isti'anah lebih memahami pentingnya melakukan disinfaksi pada area panti asuhan dan ketaatan para pengasuh dan anak-anak asuh dalam menggunakan masker ketika berinteraksi di lingkungan Panti Asuhan.

\section{Saran}

Adapun saran untuk para pengurus Panti Asuhan Al-Isti'anah yakni pelaksaan kegiatan disinfaksi pada area panti asuhan sebaiknya tetap dilasanakan, minimal pelaksaanan 1 minggu sekali. Selain itu disetiap kegiatan sekirannya para pengurus dan penghuni Panti Asuhan Al-Isti'anah selalu menggunakan masker. Secara umum pelaksanaan kurang maksimal karena dilaksanakan hanya pada Panti Asuhan Al-Isti'anah Kediri Kabupaten Lombok Barat. Kegiatan ini membantu meningkatkan pengetahuan masyarakat tentang pola hidup bersih dan sehat sehingga masyarakat akan terbiasa dan berpola hidup sehat dan bersih apalagi dalam pandemi covid-19. Oleh karena itu bagi para tim kegiatan pengabdian lainnya sekirannya kegiatan ini terus dilaksanakan khususnya untuk lokasi-lokasi atau tempat-tempat masyarakat sering berkumpul, apalagi dalam masa pandemi covid-19 karena dapat memberikan bantuan bagi masyarakat yang membutuhkan donasi alat kesehatan seperti masker, alat desenfektan dan cairan desinfektan. 


\section{Daftar Pustaka}

Athena., Laelasari, E., \& Puspita, T. (2020). Pelaksanaan Desinfaksi dalam Pencegahan Penularan Covid-19 dan Potensi Risiko Terhadap Kesehatan di Indonesia. Jurnal Ekologi Kesehatan, 19(1), 1-20. doi: https://doi.org/10.22435/jek.v19i1.3146

Dinas Kesehatan NTB. Diperoleh pada 3 Februari 2021, dari DATA Covid-19 NTB website: https://corona.ntbprov.go.id/

Fitriasari, N. (2020). Pencegahan Primer Membentuk Masyarakat Sehat Di Era Covid-19. SALAM: Jurnal Sosial \& Budaya Syar-I, 7(12), 1153-1166. doi: https://doi.org/10.15408/sjsbs.v7i7.15407

Gugus Tugas Percepatan Penanganan Covid-19. Diperoleh pada 15 Desember 2020, dari Data Sebaran Covid-19 website: https://covid19.go.id/

Ihsan, S., Pascayantri, A., \& Ruslin. (2020). Penguatan Peran Warga Masyarakat Dalam Mitigasi dan Adaptasi Menghadapi Wabah Covid-12 di Kabupaten Konawe Kepulauan Provinsi Sulawesi Tenggara. ANOA(Jurnal Pengabdian Masyarakat), 1(3), 227-237. doi: http://dx.doi.org/10.52423/anoa.v1i3.13641

Indrawati., Risfianty, D K., \& Fitriyah, L. (2020). Masker Gratis dan Informasi Social Distancing Bagi Masyarakan Dusun Montong Are Tengah. Intan Cendikia (Jurnal Pengabdian Masyarakat), 1(1), 1-8.doi: https://doi.org/10.47165/intancendekia.v1i1.54

Larasati, A L., Hariwibowo, C. (2020). Penggunaan Desinfektan dan Antiseptik pada Pencegahan Penularan Covid-19 di Masyarakat. Majalah Farmasetika, 5(3), 137-145.

Mahendra, Andre., Utomo, B S., Amaliyah, Faidatul., Sufia, Fajriyatus., Abdullah, Farhan. (2020). Penyemprotan Disinfektan dan Pembagian Alat Kesehatan (Masker) Sebagai Upaya Mahasiswa KKN BMC UNNES 2020 dalam Pencegahan Penyebaran Covid-19 di Kabupaten Demak. Abdima: Artikel Pengabdian Masyarakat Universitas Negeri Semarang.

Meri., Khusnul., Suhartati, R., Mardiana, U., \& Nurpalah, R. (2020). Pemberdayaan Masyarakat dalam Menggunakan Hand Sanitiser dan Masker Sebagai Upaya Prefentiv terhadap Covid-19. Bantenese (Jurnal Pengabdian Masyarakat), 2(1), 26-33. doi: https://doi.org/10.30656/ps2pm.v2i1.2340

Risfianty, D., \& Indrawati, I. (2020). Pemberdayaan Kesehatan Masyarakat Melalui Pengadaan Fasilitas Cuci Tangan pada Masa Pandemi Covid-19 di Masjid dan Mushala Dusun Montong Are Tengah. Jurnal Pengabdian UNDIKMA, 1(2), 94-99. doi: https://doi.org/10.33394/jpu.v1i2.2724

Rusdi, M S., Efendi, M R., Afriyani., Rustini., Putri, L E., Kamal S., \& Surya S. (2021). Edukasi Penerapan Perilaku Hidup Bersih dan Sehat (PHBS) sebagai Upaya Pencegahan Penyebaran Covid-19. Jurnal Altifani Penelitian dan Pengabdian kepada Masyarakat, 1(1), 47-51. doi: https://doi.org/10.25008/altifani.v1i1.123

WHO. (2020). Naming The-Coroviruses Disease (Covid-19) and The Virus That Cause It. Geneva : World Health Organization. 